\title{
Histiocitose de Células de Langerhans: Relato de Caso
}

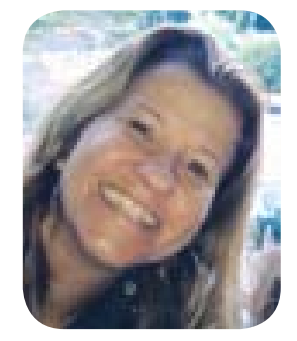

\author{
Romeo, M. ${ }^{1}$, Silva, M. F. T. ${ }^{2}$, Quixadá, M. A. G. ${ }^{2}$ \\ Palavras-chave: histiocitose, células de Langerhans, tratamento
}

\section{INTRODUÇÃO}

Histiocitose de células de Langerhans (HCL) é uma patologia rara, sem etiologia definida, caracterizada por proliferação e infiltração de um ou mais órgãos, por células chamadas de histiócitos.

HCL é mais comum em crianças de 1-3 anos, com uma incidência de 3-5 indivíduos para cada 1 milhão de infantes, enquanto na população adulta essa incidência é de aproximadamente 2 casos a cada 1 milhão. ${ }^{1}$

A doença era anteriormente denominada Histiocitose $X$, porém, com a definição da origem nas células de Langerhans, o termo foi mudado para HCL. A morfologia e o imunofenótipo permitem a identificação destas células, caracterizadas pelo tamanho grande e pela expressão dos antígenos CD1a e CD207.,

\section{MANIFESTAÇÃO CLÍNICA}

As manifestações clínicas variam de acordo com o sistema afetado e com a extensão da lesão. Sintomas clínicos como erupção cutânea, dispneia ou taquipneia, polidpsia ou poliuria, dor óssea, linfadenopatia, perda de peso, febre, hipertrofia gengival, úlceras de mucosa e ataxia são mais comumente descritos ${ }^{3}$.

A doença pode ser focal ou multissistêmica, dependendo do número de órgãos acometidos. Sendo focais as formas com comprometimento de apenas um órgão ou sistema e multissistêmicas quando dois ou mais órgãos são acometidos ${ }^{3,4}$.

$\mathrm{Na}$ maioria dos pacientes adultos (55\%), a doença se manifesta em apenas um sistema, sendo o sistema esquelético o mais comum $(77 \%)$, seguido por pele / mucosas (39\%), linfonodos (19\%) e fígado $(16 \%)^{5}$.

O prognóstico depende da classificação da doença em focal ou multissistêmica, bem como de quais são os órgãos/sistemas acometidos. O envolvimento de órgãos do sistema hematopoiético, fígado, ossos da face e coluna caracterizam uma doença de alto risco e de pior prognóstico, já o envolvimento de pulmões não parece se associar com piora na sobrevida. ${ }^{6,7}$

\section{DIAGNÓSTICO}

Histiocitose de células de Langehans é um diagnóstico desafiador devido ao espectro de manifestações clínicas e sobreposição com condições mais comuns. Estudos mostram que o tempo para diagnóstico é em média 1 a 4 anos após o início dos sintomas. A biópsia excisional é a forma ideal para obter uma amostra com arquitetura intacta e a demonstração de histiócitos com imunofenótipo característico ${ }^{3}$.

\section{TRATAMENTO}

O tratamento deve ser estratificado de acordo com a classificação de risco da doença, podendo variar de terapia tópica, corticoide, retirada cirúrgica de lesão ou quimioterapia sistêmica. Para pacientes com doença localizada e sem envolvimento de órgãos considerados de risco, terapias tópicas, corticoide e cirurgia podem ser curativos. Nos casos de alto risco com acometimento de múltiplos sistemas e órgãos de risco, os estudos sugerem iniciar com esquema de tratamento mais agressivo, associando corticoide com mono ou poliquimioterapia, por cerca de $\mathrm{ano}^{7}$.

\section{CASO CLÍNICO}

Paciente masculino, 34 anos, diabético, apresentou ferimento infectado em coxa esquerda há 1 ano. Foi internado por 2 vezes para antibioticoterapia venosa com melhora apenas parcial. Informa que em um dos internamentos a antibioticoterapia foi prolongada por suspeita de Osteomielite. Há 3 meses do diagnóstico, apresentou piora das lesões, quando foram biopsiadas. Os exames anatomopatológico e imuno-histoquímico definiram a infiltração neoplásica da pele por histiócitos, concluindo como Histiocitose de Células de Langerhans. 
As tomografias de estadiamento mostraram que, além do acometimento cutâneo, havia também o envolvimento de gânglios retroperitoneais e de fígado. A doença foi considerada como multissistêmica, considerando o acometimento dos três locais acima. Foi iniciado o esquema de quimioterapia sistêmica com metotrexato $32 \mathrm{mg}$ semanal e 6-mercaptopurina 100 $\mathrm{mg}$, diariamente, com programação de 12 meses de tratamento.

O paciente, no momento da publicação deste artigo, encontrava-se com cerca de 1 mês de tratamento, sendo observada a melhora das lesões, com redução da drenagem de secreção e evolução para cicatrização, como mostra a figura 1.

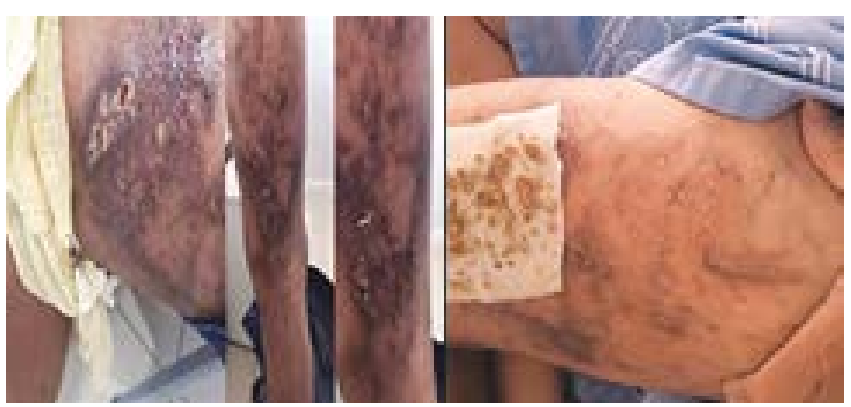

Figura 1 - Lesões em coxa esquerda compatíveis com Histiocitose de Langerhans antes e após 20 dias de iniciado o tratamento.

\section{CONCLUSÃO}

$\mathrm{O}$ caso reportado nos mostra que a HCL, apesar de mais comum, não é restrita a população pediátrica, podendo ser encontrada em adultos. A diversidade da apresentação clínica dificulta e retarda o diagnóstico em grande parte dos casos. Embora o curso clínico seja benigno na maior parte dos casos, existe uma morbidade considerável ligada à própria doença, assim como ao tratamento. O diagnóstico preciso e mais precoce, com a doença na forma mais localizada, portanto de melhor prognóstico, pode reduzir sequelas permanentes e melhorar as taxas de sobrevida.

\section{REFERÊNCIAS}

1. Jaffe R. The diagnostic histopathology of Langerhans cell histiocytosis. In: Histiocytic Disorders of Children and Adults. Basic Science, Clinical Features, and Therapy, Weitzman S, Egeler RM (Eds), Cambridge University Press, Cambridge 2005. p.14.

2. Emile JF, Abla O, Fraitag S, et al. Revised classification of histiocytoses and neoplasms of the macrophage-dendritic cell lineages. Blood 2016; 127:2672.
3. McClain KL. Clinical manifestations, pathologic features, and diagnosis of Langerhans cell histiocytosis. In: UpToDate, Post TW (Ed), UpToDate, Waltham, MA. (Acessado em 05 de maio de 2017.)

4. Braier J, Latella A, Balancini B, et al. Outcome in children with pulmonary Langerhans cell Histiocytosis. PediatrBloodCancer 2004; 43:765

5. Grois N, Pötschger U, Prosch H, et al. Risk factors for diabetes insipidus in langerhans cell histiocytosis. Pediatr Blood Cancer 2006; 46:228.

6. Odame I, Li P, Lau L, et al. Pulmonary Langerhans cell histiocytosis: a variable disease in childhood. Pediatr Blood Cancer 2006; 47:889.

7. Carl E. Allen, Stephan Ladisch, and Kenneth L. McClain. How I Treat Langerhans Cells Histiocytosis. Blood. 2015 Jul 2;126(1):26-35

1- Serviço de Hematologia do HSI

2- Serviço de Oncologia Clínica do HSI

Endereço para correspondência: mauraromeo@yahoo.com.br 